\title{
The Use of Internet and Social Media : Study on Tax Information Seeking Behavior Among Indonesian Taxpayers During COVID-19 Pandemic
}

\author{
S M I Setyawati', A N Rahmanto ${ }^{2}$, I A Satyawan ${ }^{3}$ \\ ${ }^{123}$ Magister of Communication Science Program, Sebelas Maret University, Surakarta, Indonesia \\ ${ }^{1}$ santimaria.is@student.uns.ac.id, ${ }^{2}$ andreyuda@gmail.com, ${ }^{3}$ agungsatyawan@staff.uns.ac.id
}

\begin{abstract}
This study aims to investigate the use of the internet and social media for tax information seeking among Indonesian Taxpayers in Indonesia during the COVID-19 pandemic. This research was conducted with a quantitative approach by using the survey method. A total of 202 Taxpayers participated in our survey, and we found that 196 respondents (97\%) accessed Google, 176 respondents (87,1\%) accessed Pajak.go.id and 99 respondents $(49 \%)$ accessed Youtube for seeking the tax information. Google appears to be the more appropriate and familiar search engine for the participants. Pajak.go.id was rated more appropriate because it is the official government tax website. Youtube was dominant because it is rated as more informative. Considering the pattern of Taxpayers behavior in seeking tax information, tax information providers could provide tax information on the appropriate channel to answer the taxpayer's needs for information.
\end{abstract}

Keywords: Tax Information Seeking, Internet, Social Media, Taxpayers

\section{Introduction}

Indonesia adopts the self-assessment method in taxation. In the self-assessment method, the government has given thrust for its Taxpayers to calculate and report the tax due by themself. That degree of trust implies that the government has to assume that the public could understand the tax regulation while also capable to fulfill their tax obligation independently [1]. In that situation, Taxpayers need to increase their tax knowledge to comply their tax obligation [2]. To meet these knowledge need, the Taxpayers conduct to searching the tax information. The need for individuals to acquire knowledge encourages information seeking behavior [3], [4].

Before the pandemic, Taxpayers can simply visit the Tax Office to ask for information directly, buat the plague have rendered this method unavailable due to the DGT's (Directorate General of Taxes) decision to stop all face-to-face tax services that were normally accessible from Integrated Service Centre across Indonesia [5]. This closure has occurred from March 16th, 2020, and then extended until June 14th, 2020 [6], [7]. The closure has affected how the public seeks information about tax because they cannot see the tax officer directly anymore. Despite that, the public can still search for tax information indirectly via phone, email, or accessing the internet and social media [8]. 
In this era of information and technological advancement, the internet and social media have become a digital platform that massively utilized by the public to search for information [9]. From the data that were collected by We Are Social and Hootsuite in April 2020, it was found that the internet has been used by as high as $59 \%$ of the global population, while social media have been used by $49 \%$ of the global population [10]. This number has been increased to $64 \%$ and $59 \%$ respectively by early 2020 . These numbers indicated that internet users were increased by $17 \%$ compared to the data from 2019 , while the social media user was also showing $8,1 \%$ growth from 2019 [11]. The availability of internet access facility has been rendering the information searching activity much easier. The society also tends to use social media to seek and distribute information, because the public could utilize social media as a tool to participate productively in the identification of some problems with relatively low cost [12].

As one of the government-affiliated providers of public tax information, the DGT created a particular website as a dissemination medium for tax information on www.pajak.go.id [13]. The DGT also manages some social media accounts as an easily-accessible education media for the public. These websites and social media account were one of many of the Indonesian government's communication and education strategies to increase taxpayer's tax obedience [14]-[16]. Aside from the official government website, some websites provide taxinformations in their partnership with the government, such as ortax.org, pajak-online.com, pajakku.com, and many more. This implicates that there is enough information on the internet and social media for Indonesian taxpayers to increase their understanding of tax.

From those backgrounds, this study aims to fill in the lack of research to study the individual Taxpayer's patterns in their tax information seeking behavior using the internet and social media during the pandemic COVID-19 period, especially as an effect of the temporary closing of the Tax Office services in Indonesia.

\section{Method}

This research was conducted with a quantitative descriptive approach by using the survey method to study the use of the internet and social media for seeking tax information among Indonesian Taxpayers during the COVID-19 pandemic. A survey method is a research methodology where a questionnaire is utilized as a data-collecting instrument [17]. The deployed questionnaire covers some single and multiple-answer questions about accessed search engine, website, and social media they accessed during seeking the tax informatin, which search engine, website, and social media that they preferred, and why they deem those media to be more appropriate for them. The data was collected from June 20th, 2020 until 13th July 2020.

Subjects on this study were limited to individual Indonesian Taxpayers that were looking for tax information via the internet and social media on the period of the COVID-19 pandemic (from mid-March 2020 until the end of June 2020), where on that period, the closing of the Tax Office and all of its face-to-face services occurred. Considering that the population size of Taxpayers that become online information seekers cannot be accurately determined, this study utilized a non-probability sampling method in form of incidental sampling [18]. As the size of 
samples needed, researchers use the Lemeshow sample formula [19] that operates as follows:

$$
\mathrm{n}=\frac{\mathrm{Z}^{2} \mathrm{p}(1-\mathrm{p})}{\mathrm{d}^{2}}
$$

Where $\quad \mathrm{n}=$ minimal sample size required

$\mathrm{Z}=\mathrm{z}$ score

$\mathrm{p}=$ prevalance outcome

$\mathrm{d}=$ distance (percentage points of the true proportion)

Based on the Lemeshow formula, if the resulting estimate is to fall within 10 percentage points of the true proportion with $99 \%$ confidence $(\mathrm{z}$ score $=2,576)$ and used maximal estimation $\mathrm{p}=50 \%$, the required minimum sample size is 167 respondent.

\section{Result And Discussion}

Of the 457 questionnaires distributed, 209 results in feedback (with a response rate of $45,73 \%$ ). Out of those 209,7 of them were not registered as an Indonesian taxpayer, so the researcher drops them and uses 202 respondents as participants of this study.

Table 1. Respondent's Characteristic

\begin{tabular}{|c|c|c|}
\hline \multirow{2}{*}{$\begin{array}{l}\text { Parameter } \\
\text { Participant Sex, n (\%) }\end{array}$} & \multicolumn{2}{|c|}{ Total $\mathrm{N}=202$} \\
\hline & & \\
\hline Male & 133 & $65,8 \%$ \\
\hline Female & 69 & $34,2 \%$ \\
\hline \multicolumn{3}{|l|}{ Age, n (\%) } \\
\hline $18-25$ years old & 8 & $4,0 \%$ \\
\hline 26-35 years old & 58 & $28,7 \%$ \\
\hline $36-45$ years old & 50 & $24,7 \%$ \\
\hline $45-55$ years old & 60 & $29,7 \%$ \\
\hline $56-65$ years old & 24 & $11,9 \%$ \\
\hline$>65$ years old & 2 & $1,0 \%$ \\
\hline \multicolumn{3}{|l|}{ Education Level, n (\%) } \\
\hline Bachelor/Master/Doctoral & 201 & $99,5 \%$ \\
\hline Senior High & 1 & $0,5 \%$ \\
\hline \multicolumn{3}{|l|}{ Employment, $\mathrm{n}(\%)$} \\
\hline Employee & 172 & $85,2 \%$ \\
\hline Entrepreneur & 13 & $6,4 \%$ \\
\hline Retired & 6 & $3,0 \%$ \\
\hline $\begin{array}{l}\text { Other, mention by respondents as free text } \\
\text { (commissioner, professionals, social worke }\end{array}$ & $\begin{array}{c}11 \\
\text { yman) }\end{array}$ & $5,4 \%$ \\
\hline
\end{tabular}

From 202 participants, $65,8 \%$ of them were male and $34,2 \%$ were female with average age of 42,8 years old. Most of them (99,5\%) have had a bachelor/master/doctoral education and only one of them has a background of senior high school. The majority $(85,2 \%)$ of the 
articipants works as either government civil employee or private employee (for the detail see in Table 1).

\subsection{Internet and Social Media Use for Tax Information Seeking}

Table 2 presents the survey result for what search engine, website, and social media they were using and which are the most appropriate for them when they seeking the tax information across the internet.

Table 2. Internet and Social Media Used for Tax Information Seeking

\begin{tabular}{|c|c|c|c|c|}
\hline \multirow{2}{*}{\begin{tabular}{|l|} 
Variabel \\
Search Engine, n (\%)
\end{tabular}} & \multicolumn{2}{|c|}{ Media Used*) } & \multicolumn{2}{|c|}{$\begin{array}{c}\text { Preferable Media } \\
\text { for Used }\end{array}$} \\
\hline & & & & \\
\hline Google & 196 & $97,0 \%$ & 192 & $95,0 \%$ \\
\hline Yahoo & 18 & $8,9 \%$ & 1 & $0,5 \%$ \\
\hline Bing & 7 & $3,5 \%$ & 1 & $0,5 \%$ \\
\hline MSN & 4 & $2,0 \%$ & 1 & $0,5 \%$ \\
\hline Duckduck.go & 2 & $1,0 \%$ & 2 & $1,0 \%$ \\
\hline Not Using & 5 & $2,5 \%$ & 5 & $2,5 \%$ \\
\hline \multicolumn{5}{|l|}{ Website, n (\%) } \\
\hline pajak.go.id & 176 & $87,1 \%$ & 133 & $65,8 \%$ \\
\hline online-pajak.com & 91 & $45,0 \%$ & 24 & $11,9 \%$ \\
\hline ortax.org & 84 & $41,6 \%$ & 32 & $15,8 \%$ \\
\hline pajakku.com & 31 & $15,3 \%$ & 2 & $1,0 \%$ \\
\hline ddtc.co.id & 6 & $3,0 \%$ & 1 & $0,5 \%$ \\
\hline wibowopajak.com & 1 & $0,5 \%$ & 1 & $0,5 \%$ \\
\hline efakturespt.com & 1 & $0,5 \%$ & 0 & $0,0 \%$ \\
\hline efile.com & 1 & $0,5 \%$ & 1 & $0,5 \%$ \\
\hline Unknown (forget, other blog) & 3 & $1,5 \%$ & 3 & $1,5 \%$ \\
\hline Not Using & 5 & $2,5 \%$ & 5 & $2,5 \%$ \\
\hline \multicolumn{5}{|l|}{ Social Media, n (\%) } \\
\hline Youtube & 99 & $49,0 \%$ & 73 & $36,1 \%$ \\
\hline Instagram & 79 & $39,1 \%$ & 52 & $25,7 \%$ \\
\hline Facebook & 55 & $27,2 \%$ & 23 & $11,4 \%$ \\
\hline Twitter & 47 & $23,3 \%$ & 30 & $14,9 \%$ \\
\hline Other (Whatsapp, Webinar) & 7 & $3,5 \%$ & 0 & $0,0 \%$ \\
\hline Prefer Not & 0 & $0,0 \%$ & 24 & $11,9 \%$ \\
\hline
\end{tabular}

Results suggest that Google is the most common search engine used (97\%) by participants across all age and gender segmentation, while the website pajak.go.id were absolutely popular website on tax information seeking (87,1\%). Surprisingly, Youtube was rated as the most 
popular social media to search for tax-related information, which is interesting when we consider that the main feature of Youtube is user-generated videos.

The site Pajak.go.id turns to be the most referenced website for taxpayers. This site has been known as the official government website that provides tax-related information for the general public. Meanwhile, the non-governmental website pajak.com and ortax.org were also accessed quite a lot by our participants ( $45 \%$ and $41,6 \%$ respectively).

Youtube becomes the most accessed social media when our participants seek tax-related information within social media (49\%), with more than half of its $49 \%$ user belong to the 46 55 age category. Besides Youtube, 39,1\% reports that they search for the information they needed using Instagram, with the dominant age of 18-25 years old.

Google, Pajak.go.id, and Youtube also rated as the most appropriate channel to fulfill they need to search tax-related information on their respective category, in which Google as a search engine, Pajak.go.id as a website, and Youtube as a social media.

The results also record different trends among the age and gender groups on the matters of social media preference. Facebook and Youtube are more popular on male participants, whereas Twitter and Instagram are more popular on female participants, especially Instagram that even more popular than Youtube on female respondents (Youtube: 42\%, Instagram $50,7 \%)$.

Across age group, Instagram becomes less popular along with the increase of age, whereas Facebook and Youtube seem to be stronger along with the increase of age although in the case of Facebook, this finding was restricted on respondents with the age group of 18-55 years old.

The difference of the dominant social media across gender and age group indicating that the social media preference has been influenced by age and gender, which hints at the importance of a good target segmentation and a precise social media channel as a means to provide taxpayer's needs of information.

\subsection{Respondent's Reason for the Media Preferences}

Table 3 presents the reason why participants feel that they are more inclined in using a particular search engine, website, or social media in their effort to search for information. Our survey results indicate that Google has become the most accessed search engine due to its familiarity and user-friendliness. Google also deemed capable to bring up much alternative information. This reason can be understood further when we notify ourselves with search engine characteristics. On internet-based information search, peoples use the search engine as a tool to browse through many information sources spread across the internet, where they become involved on many models of information searching that utilizing keywords input that guides the user to decides on which site to access on the search engine's search result page [20]. 
Tabel 3. The Respondent Reason for Using Preferences Media

\begin{tabular}{|lrr|}
\hline Respondent's Reason for Using Preferences Media & $\mathbf{N}=\mathbf{2 0 2}$ \\
\hline Search Engine, $n$ (\%) & 161 & $79,7 \%$ \\
More familiar & 61 & $30,2 \%$ \\
Bring up many alternative information & 57 & $28,2 \%$ \\
User friendly & 34 & $16,8 \%$ \\
Up to date & 33 & $16,3 \%$ \\
Accurate & 2 & $1,0 \%$ \\
Privacy reason & & \\
& & \\
Website, n (\%) & 118 & $58,4 \%$ \\
Official website form Goverment & 66 & $32,7 \%$ \\
Informative & 60 & $29,7 \%$ \\
Recommended & 27 & $13,4 \%$ \\
User friendly & 9 & $4,5 \%$ \\
Attractive design and layout & 1 & $0,5 \%$ \\
More familiar & 1 & $0,5 \%$ \\
Accessable & 1 & $0,5 \%$ \\
Easy to understand & 1 & $0,5 \%$ \\
Can help fill in tax rep orting at once & 1 & $0,5 \%$ \\
As needed & & \\
Social Media, n (\%) & & \\
More familiar & & \\
Easy to understand & 98 & $48,5 \%$ \\
Complete & 63 & $31,2 \%$ \\
There are special account for tax & 50 & $24,8 \%$ \\
Only have this type of social media & 30 & $14,9 \%$ \\
Not using & 28 & $13,9 \%$ \\
Provide a tutorial & 18 & $8,9 \%$ \\
Officoal account from Goverment & 3 & $1,5 \%$ \\
Provide a visual content & 2 & $1,0 \%$ \\
See the update infromation from friend's account who as a fiscus & 1 & $0,5 \%$ \\
\hline
\end{tabular}

* Respondents could select more than one option

Source : Primarily data processing

The website Pajak.go.id has become the most accessed reference $(87,1 \%)$ and also the most appropriate $(65,8 \%)$ for our participants to acquire tax information because of its role as the official government tax website, wherein it also rated as informative and recommended by their peers. Nonetheless, the fact that Pajak.go.id is the official government website explains more $(58,4 \%)$ about its popularities, indicating the needs of some sort of "official" information in searching for relatively important information such as taxation literature. although research shows that the transparency level of government websites in Indonesia is less transparent [21], but in this study it was found that most respondents chose to access Pajak.go.id as a government website as a reliable source of tax information. In the other side, the government website rated as capable of providing the needed information, emphasizing the function of e- 
knowledge, while also credible [22]. This finding indicates that the government has made the right call when they decide to set up the official tax website.

As many as 73 Youtube user feels that Youtube was more appropriate for their need. Information provided by Youtube was rated as more understandable and more familiar, which becomes the reason for its popularity on taxpayers/information seeker. This results reinforced by the 2013 study by Prybutok, in which it confirms Youtube as a reference for its users to communicate and educates themselves about health. The use of Youtube as a channel for education and information has been deemed effective before [23].

Further investigation upon participant's reason on their preferred media reveals some unique characteristics of why some of those tools were chosen. These patterns of preference can be reviewed deeper using the uses and gratification theory which first developed by Elihu Katz [24]. A user has all the freedom to choose where they will independently which media were more appropriate to fulfill their needs [25]-[27]. Base on this theory, the audience was always an active elector that chooses many media options to fulfill their personal needs [28]. This implicates that the media that were more capable of answering the user's needs will be selected to fulfill the user needs for information.

One of the more unique characteristics of the taxpayer behavior in search of taxation information is the use of the search engine Duckduck.go found in a small fraction of our respondents. Duck duck.go only used by $1 \%$ (two participants) of our respondents, but those two respondents similarly express that they trust Duckduck.go could provide them with privacy and anonymity when seeking tax information, indicating the needs to hide their identity while they browse about taxation.

The user tendency to seek for the most easy-to-understand while the most appropriate for their needs also found on participants that accessing ddtc.co.id, wibowopajak.com, and efile.com. Participants that accessed these sites are small in number, but they have reasons exclusive on these respective websites. One user of ddtc.co.id was the most updated content with an interface that was easy to use. One user of wibowopajak.com has chosen the website because he feels that the content provided by the website was easy to understand. The sole user of efile.com, on the other hand, prefer this website because the website also provided an online form facility to input his tax form.

Albeit small in numbers, these unique reasons can lead the participants to independently chose a particular media. The motive behind those decisions was the gratifications they receive when they accessed a certain searching media. These findings were in line with the uses and gratification theory, in which the gratification the user receives determined by the user's characteristics and their belief in the media [29]. One of the reasons that people choose a certain media for their media consumption is to get information as one of potential gratification [30].

Both the common and more dominant findings and the unique, minor findings of this study could be utilized as a reference for the taxation information provider in understanding the motivation and dynamics behind people's choice in accessing media. The data that conclude which media were more dominant can be harnessed by the taxation information provider to determine which channel would be more relevant for the respondents from a certain demographic category. For example, we can guide the taxation communication and education strategies towards the most optimal media channel based on the main target age of the strategies. 
Especially for the official government tax organization, these findings are relevant because the availability of precise information that can cater to the taxpayer's needs is an important advocate for taxpayer's tax knowledge. Tax knowledge is one of the key attributes that reflect the taxpayer's tax compliance so it should be enhanced through adequate and accurate providence of taxation information [31]. The availability of adequate, accessible, and wellfitted to the taxpayer's preference will increase the public's tax knowledge what should lead to growth in tax compliance [32]. Moreover, the key performance indicator of DGT is the accomplishment of the targetted rate of tax compliance. The providing of taxation information that oriented on the fulfillment of information needs among taxpayers can become a strategic move for DGT to face the many changes of the "New Normal" period. The DGT should prepare themselves in many dimensions, both on the service as well as their function as tax system educators for the society.

\section{Conclusion}

Amidst the deprivation of direct information access due to the COVID-19 Pandemic, the internet, and social media have become a proper alternative source for tax information seeking among taxpayers. Based on the survey to the 202 respondents, we found that the most of participants accessed Google search engine, Pajak.go.id website, and Youtube channel for seeking tax information. Google, Pajak.go.id, and Youtube also rated as the most appropriate media to fulfill they need in searching tax information on their respective category. Understanding this behavior could be pivotal for tax information provided on building more precise communication and dissemination strategies on the right media channel that could answer the Taxpayer's needs. So that it could support the growth of tax knowledge and increase the tax compliance.

\section{Acknowledgments}

The researchers would like to thank in advance to all of the respondents for the willingness to participate in fulfilling the questionnaire for this study.

\section{References}

[1] Mardiasmo, Perpajakan. Yogyakarta: Penerbit Andi, 2016.

[2] A. O. Oladipopu and U. Obazee, "Tax Knowledge, Penalties, and Tax Compliance in Small and Medium Scale Enterprises in Nigeria," iBusiness, vol. 8, pp. 1-9, 2016.

[3] T. D. Wilson, "Models in Information Behavior Research," J. Doc., vol. 55, no. 3, pp. 249-270, 1999.

[4] D. Ellis, "Modeling the Information-Seeking Patterns of Academic Researchers: A Grounded Theory Approach," Libr. Q., vol. 63, no. 4, pp. 469-486, 1993.

[5] Directorate General of Taxes, "Announcement Number 3 / PJ.09 / 2020 About Announcement of Extension of Taxation Services Without Advance." 2020. 
[6] Directorate General of Taxes, "Announcement of Extension of Taxation Service Time Without Face to Face," 2020. https://www.pajak.go.id/pengumuman/pengumuman-perpanjangan-waktupelayanan-perpajakan-tanpa-tatap-muka-0 (accessed Jun. 18, 2020).

[7] Directorate General of Taxes, "Face to Face Tax Service Reopens June 15, 2020," 2020. https://www.pajak.go.id/siaran-pers/layanan-perpajakan-tatap-muka-dibuka-kembali-15-juni2020 (accessed Jun. 18, 2020).

[8] Directorate General of Taxes, "DGT Adopts New Normality Protocol," 2020. https://www.pajak.go.id/covid19 (accessed Jun. 18, 2020).

[9] PEW Research Centre, "Science News and Information Today," 2020. https://www.journalism.org/2017/09/20/science-news-and-information-today (accessed Jun. 18, 2020).

[10] We Are Social, "Digital 2020: 3.8 billion people use social media," 2020. https://wearesocial.com/blog/2020/01/digital-2020-3-8-billion-people-use-social-media (accessed Jun. 18, 2020).

[11] We Are Social and Hootsuite, "Digital 2020: Indonesia," 2020. https://datareportal.com/digitalin-indonesia (accessed Jun. 18, 2020).

[12] A. M. Kaplan and M. Haenlein, "Users of the world, unite! The challenges and opportunities of Social Media,” Bus. Horiz., vol. 53, no. 1, pp. 59-68, 2010, doi: 10.1016/j.bushor.2009.09.003.

[13] Online-Pajak, "Official Tax and Goverment-Owned Website You Need To Know," 2018. https://www.online-pajak.com/tentang-pajakpay/website-pajak-resmi (accessed Jun. 18, 2020).

[14] Directorate General of Taxes, "Directorate General of Taxation Maximizes Social Media Spread Tax Information," 2019. https://www.pajak.go.id/berita/ditjen-pajak-maksimalkan-mediasosial-sebar-informasi-perpajakan (accessed Jun. 18, 2020).

[15] Directorate General of Taxes, "Decree of the Director General of Tax Number KEP-273 / PJ / 2013 concerning Management of Accounts of the Directorate General of Taxes in Social Media Networks." 2013.

[16] Directorate General of Taxes, "Decrees of the Director of Counseling, Services and Public Relations Number KEP-03 / PJ.09 / 2015 about the Directorate General of Tax's Official Social Media Account Management Team." 2015.

[17] M. Singarimbun and S. Effendi, Metode Penelitian Survei. Jakarta: LP3ES, 1989.

[18] Sugiyono, Metode Penelitian Kuantitatif Kualitatif dan R\&D. Jakarta: Alfabeta, 2006.

[19] S. A. Ogston, S. Lemeshow, D. W. Hosmer, J. Klar, and S. K. Lwanga, "Adequacy of Sample Size in Health Studies.," Biometrics, vol. 47, no. 1, p. 347, 1991, doi: 10.2307/2532527.

[20] C. W. Choo, B. Detlor, and D. Turnbull, "Information Seeking on the Web: An Integrated Model of Browsing and Searching," First Monday, vol. 5, no. 2, 2000, [Online]. Available: http://firstmonday.org/issues/issue5_2/choo/index.html.

[21] A. Bahari, A. Djunid, H. Putri, A. P. Vittra, and A. T. Dwiputri, "Analysis of Local Government Web Transparency of South Eastasia Countries: A Case Study in Indonesia," in The International Conference on ASEAN 2019, 2019, pp. 36-47, doi: https://doi.org/10.1515/9783110678666-007.

[22] H. Hoesin, H. Setiadi, N. A. Lemmung, P. A. Tonandriv, and Abdulloh, "Penilaian Situs Pemerintah Daerah di Provinsi DKI Jakarta, Bengkulu, Jambi, dan Bangka Belitung," 2008.

[23] G. L. Prybutok, "YouTube: An Effective Web 2.0 Informing Channel for Health Education to Prevent STDs," Informing Sci. Int. J. an Emerg. Transdiscipl., vol. 16, 2013.

[24] E. Griffin, A. Ledbetter, and G. Sparks, A First Look at Communication Theory, 10th ed. New York: McGraw-Hill Education, 2019.

[25] J. G. Blumler and E. Katz, The Uses of Mass Communications: Current Perspectives on Gratifications Research. California: Sage, 1974.

[26] D. McQuail, Mass Communication Theory: An Introduction, 2nd ed. Newbury Park, CA: Sage, 1987.

[27] C. D. Reinhard and B. Dervin, "Media Uses and Gratifications," in 21st Century Communication: A Reference Handbook, 2nd ed. Thousand Oaks, CA: Sage, 2009.

[28] Stephen W. Littlejohn, K. A. Foss, and J. G. Oetzel, Theories Of Human Communication 
Eleventh Edition, vol. 53, no. 95. 2012.

[29] P. Palmgreen, Uses and Gratification: A Theorical Perspective on Communication Yearbook 8. Beverly Hills, CA: Sage, 1984.

[30] A. M. Rubin, "Uses-And-Gratifications Perspective on Media Effects," in Media Effects: Advances in Theory and Research. New York: Lawrence Erlbaum, 2009.

[31] M. Syafriel, "The Atributes of Personal Taxpayer's Compliance in Indonesia," Accountability, vol. 7, no. 2, pp. 48-63, 2018.

[32] A. Pratama, "Individual Taxpayer Characteristics and Taxpayer Knowledge: Exploratory Survey on Individual Taxpayers in Bandung City, Indonesia," Rev. Integr. Bus. Econ. Res., vol. 7, pp. 338-349, 2018. 